\title{
Pengembangan Perangkat Pembelajaran Matematika Berbasis Problem Based Learning untuk Memfasilitasi Kemampuan Pemecahan Masalah Matematis Siswa Pada Materi Barisan dan Deret Kelas X SMK/MAK
}

\author{
Yasvialan Arianta $^{1}$, Titi Solfitri ${ }^{2}$, Syarifah Nur Siregar ${ }^{3}$ \\ 1, 2, 3 Program Studi Pendidikan Matematika, FKIP Universitas Riau \\ Kampus Bina Widya Km 12,5 Simpang Baru, Pekanbaru, Riau, Indonesia \\ yasvialanarianta2020@gmail.com
}

\begin{abstract}
This research was development research that aims to produce valid and practical learning tools (Syllabus, RPP, and Student Worksheet) on the material Sequences and Series of Class X Vocational High School. This research due to the importance of learning tools that can facilitate students' mathematical problem-solving abilities. This research was used ADDIE (analysis, design, development, implementation, and evaluation). The analysis phase includes some analysis (needs, curriculum, and student characteristics). Researchers designed the product at design stage than researchers develop learning tools validate by 3 validators. The average results of the validation of the syllabus, lesson plans, and Student Worksheet were 3,69, 3,67 and 3,68 respectively equal to very valid category. Small group trials were conducted on 9 students of X SMK consisting of 5 girls and 4 boys. In the evaluation stage, the researcher analyzed the student response questionnaires to evaluated practicality and evaluate the product. Due to the limitations of the Covid-19 pandemic, large group trials cannot be carried out. The average small group trial result was 80,49\% (practical category). In this research concluded that the Problem Based Learning-based learning tools for tenth grade of Vocational High School have met the valid and practical criteria.
\end{abstract}

Keywords: Mathematic Learning Tools, Mathematical Problem-Solving Ability, Sequences and Series, ADDIE Development Model

\begin{abstract}
Abstrak
Penelitian ini merupakan penelitian pengembangan yang bertujuan untuk menghasilkan perangkat pembelajaran yang valid dan praktis yaitu Silabus, RPP, dan Lembar Aktivitas Siswa (LAS) pada materi barisan dan deret kelas X SMK/MAK. Penelitian ini dilatarbelakangi oleh pentingnya perangkat pembelajaran yang dapat memfasilitasi kemampuan pemecahan masalah matematis siswa. Model pengembangan yang digunakan adalah model pengembangan ADDIE (analysis, design, development, implementation, dan evaluation). Tahap analysis memuat analisis kebutuhan, analisis kurikulum, dan analisis karakteristik siswa. Pada tahap design, peneliti melakukan perancangan produk. Pada tahap development, peneliti mengembangkan perangkat pembelajaran lalu dilakukan validasi oleh 3 orang validator. Rata-rata hasil validasi silabus, RPP, dan LAS masing-masing sebesar 3,69, 3,67, dan 3,68 dengan kategori sangat valid. Pada tahap implementation dilakukan uji coba kelompok kecil terhadap 9 orang siswa kelas X SMK (5 orang perempuan, 4 orang lakilaki). Pada tahap evaluation, peneliti menganalisis angket respon siswa untuk menilai kepraktisan LAS yang dikembangkan. Setelah dinyatakan valid dilakukan uji coba coba kelompok kecil. Adanya keterbatasan pandemi Covid-19 menyebabkan uji coba kelompok besar tidak bisa dilaksanakan. Rata-rata hasil uji coba kelompok kecil untuk LAS sebesar $80,49 \%$ dengan kategori praktis. Pada penelitian ini, perangkat pembelajaran berbasis Problem Based Learning pada materi barisan dan deret telah memenuhi kriteria valid dan praktis.
\end{abstract}

Kata kunci: Perangkat Pembelajaran Matematika, Kemampuan Pemecahan Masalah Matematis, Barisan dan Deret, Model Pengembangan ADDIE

Copyright (c) 2022 Yasvialan Arianta, Titi Solfitri, Syarifah Nur Siregar

$\square$ Corresponding author: Yasvialan Arianta

Email Address: yasvialanarianta2020@gmail.com (Kampus Bina Widya Km 12,5 Simpang Baru, Pekanbaru, Riau)

Received 12 December 2021, Accepted 15 February 2022, Published 23 February 2022

\section{PENDAHULUAN}

Kemampuan berpikir logis, kemampuan berpikir kritis, disiplin serta bertanggung jawab dinilai perlu untuk dimiliki oleh siswa di sekolah. Pemberian materi matematika di sekolah dapat membantu 
Pengembangan Perangkat Pembelajaran Matematika Berbasis Problem Based Learning untuk Memfasilitasi Kemampuan Pemecahan Masalah Matematis Siswa Pada Materi Barisan dan Deret Kelas X SMK/MAK, Yasvialan Arianta, Titi Solfitri, Syarifah Nur Siregar

siswa mehamami konsep matematis, meningkatkan kemampuan pemecahan masalah matematis sehingga siswa mendapatkan pengalaman belajar yang dapat diterapkan dalam pemecahan masalah yang relevan di kehidupan sehari-hari (Hendriana, 2017), (Goenawan dan Sri, 2017), dan (Amalya, 2019). Pemecahan masalah sebagai salah satu tujuan dari pembelajaran matematika (Goenawan dan Sri, 2017) perlu didukung dengan penyediaan perangkat pembelajaran yang sesuai. Pengembangan perangkat pembelajaran menuntut kreativitas guru dalam memilih model pembelajaran sehingga dapat disajikan konsep pembelajaran yang diharapkan. Perangkat pembelajaran dapat meningkatkan kemampuan pemecahan masalah siswa (Khomsiatun \& Retnawati, 2015), (Purnomo, 2011).

Hasil wawancara dan observasi terhadap guru dan siswa di beberapa sekolah di Pekanbaru menjadi tolak ukur pemilihan model dan materi dalam pengembangan perangkat pembelajaran yang dilakukan. Di SMKN 3 Pekanbaru, model yang digunakan dalam penyusunan perangkat pembelajaran hanya Discovery Learning. Hal ini dikarenakan guru mengalami kesulitan dalam pembuatan dan waktu yang digunakan untuk mengembangkan perangkat pembelajaran menggunakan model lain. Hal yang sama juga terlihat di SMK Telkom Pekanbaru bahwa LAS yang digunakan belum memadai. LAS yang digunakan oleh guru hanya memanfaatkan buku paket matematika dari sekolah tanpa adanya aktivitas siswa dalam mengerjakan soal dan pemecahan masalah. Peneliti juga melakukan observasi di SMKN 2 Pekanbaru, hasil observasi menyatakan bahwa guru hanya menggunakan RPP dan Silabus yang disadur dari internet. Peneliti juga melakukan wawancara terhadap 7 orang siswa SMKN 2 Pekanbaru. Sebanyak 5 dari 7 siswa mengaku kesulitan dalam memahami matematika serta merasa bingung menggunakan rumus yang akan digunakan dalam soal yang diberikan terutama pada materi barisan dan deret. Kesulitan ini juga disebabkan oleh soal yang bersifat abstrak sehingga membuat siswa kurang tertarik saat mengerjakannya.

Melihat kondisi yang ada maka ada tuntutan untuk melakukan perbaikan dalam proses pembelajaran. Perbaikan ini diawali dari perbaikan perangkat pembelajaran dengan menggunakan model pembelajaran yang mampu meningkatkan kemampuan pemecahan masalah matematis siswa. Model yang dipilih harus membantu keterlibatan aktif siswa agar fenomena Teacher Center Learning dapat diatasi.

Berdasarkan permasalahan yang telah dikemukakan, model Problem Based Learning dianggap cocok sebagai model pengembangan perangkat pembelajaran. PBL menyuguhkan situasi masalah yang bermakna kepada siswa sehingga secara tidak langsung menuntut keterlibatan aktif dari siswa (Suprihatiningrum, 2013), (Wulandari \& Surjono, 2013). Pengembangan perangkat pembelajaran berbasis PBL telah dilakukan pada penelitian terdahulu sehingga dapat dijadikan referensi dan penguatan untuk penelitian ini (Erna dkk, 2019), (Amalya, 2019), dan (Murtikusuma, 2015), (Sulastri, dkk, 2017), (Masjudin, 2016). Pada umumnya perangkat pembelajaran yang dikembangkan berbasis PBL saja, namun pada penelitian ini peneliti menambahkan indikator KPMM pada sintaks dan evaluasi yang digunakan.

Perangkat pembelajaran yang dihasilkan harus berkualitas sehingga diperlukan perangkat 
pembelajaran yang valid dan praktis. Oleh karena itu dilakukan pengembangan perangkat yang valid dan praktis melalui sebuah penelitian. Untuk mewujudkan gagasan ini, maka peneliti mengembangkan perangkat pembelajaran yang meliputi Silabus, RPP, dan LAS berbasis model PBL pada materi Barisan dan Deret kelas XI SMK/MAK.

\section{METODE}

Metode penelitian yang digunakan adalah metode Research and Development (R\&D) dengan menerapkan model ADDIE (Analysis, Design, Development, Implementation and Evaluate). Subjek uji coba terdiri dari 9 orang peserta didik SMKN 2 Pekanbaru dengan kemampuan berbeda pada uji coba kelompok kecil. Alat pengumpul data yang digunakan yaitu angket validitas Silabus, angket validitas RPP, dan angket validitas LAS untuk mengetahui validitas perangkat pembelajaran yang dikembangkan serta angket praktikalitas pengguna untuk mengetahui kategori respon pengguna terhadap LAS Barisan dan Deret berbasis model Problem Based Learning.

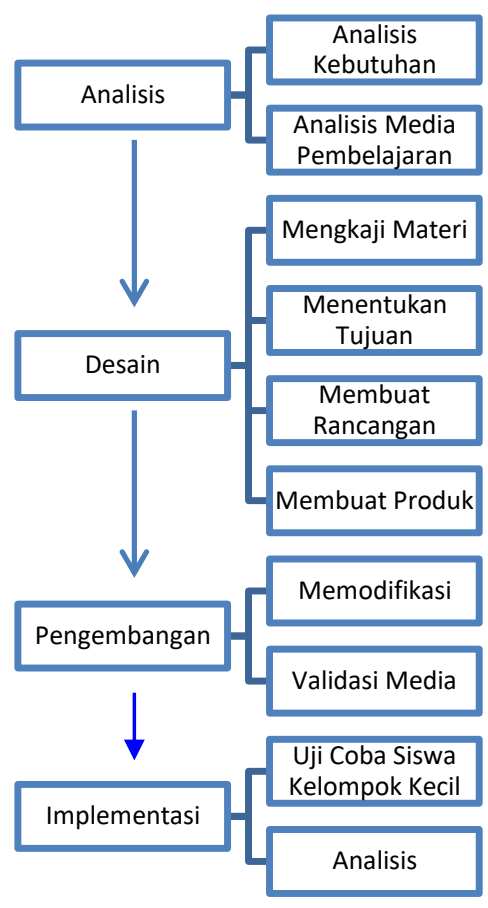

Gambar 1. Bagan Model Penelitian

Pada tahap analysis, peneliti melakukan analisis kebutuhan, analisis kurikulum, dan analisis karakteristik peserta didik. Pada tahap design, peneliti merancang produk pembelajaran sebagai produk yang akan dikembangkan dan merencanakan strategi dalam mengembangkan produk perangkat pembelajaran. Pada tahap development, peneliti melakukan pengembangan perangkat pembelajaran berupa Silabus, RPP, dan LAS yang telah direncanakan menggunakan model PBL sesuai dengan rancangan yang telah disusun. Pada tahap implementation dilakukan uji coba kelompok kecil terhadap Sembilan orang peserta didik untuk melihat kepraktisan LAS yang dikembangkan. 
Pengembangan Perangkat Pembelajaran Matematika Berbasis Problem Based Learning untuk Memfasilitasi Kemampuan Pemecahan Masalah Matematis Siswa Pada Materi Barisan dan Deret Kelas X SMK/MAK, Yasvialan Arianta, Titi Solfitri, Syarifah Nur Siregar

Pada tahap evaluation, peneliti melakukan analisis terhadap angket respon siswa untuk menilai kepraktisan dan mengevaluasi LAS yang dikembangkan.

Teknik analisis data dilakukan dengan menganalisis lembar validitas Silabus, RPP, dan LAS serta angket praktikalitas siswa berupa skala Likert 1-4. Adapun kriteria validitas yang digunakan dapat dilihat pada tabel 1 .

Tabel 1. Kriteria Validitas

\begin{tabular}{|c|c|}
\hline Interval & Kriteria \\
\hline $3,25 \leq x \leq 4,00$ & Sangat Valid \\
\hline $2,50 \leq x \leq 3,25$ & Valid \\
\hline $1,75 \leq x \leq 2,50$ & Kurang Valid \\
\hline $1,00 \leq x \leq 1,75$ & Tidak Valid \\
\hline
\end{tabular}

Suharsimi Arikunto, 2012

Dalam penelitian ini, perangkat pembelajaran matematika dinyatakan valid apabila nilai validitas yang diperoleh dari lembar validitas ahli berada pada skor minimal 2,50 artinya minimal harus memenuhi kriteria valid. Setelah LAS dinyatakan valid oleh 3 orang validator, dilakukan uji coba kelompok kecil terhadap 9 orang peserta didik dengan kemampuan heterogen sehingga diperoleh saran dan perbaikan yang digunakan untuk meminimalisir kesalahan pada LAS yang telah dibuat. Untuk mengetahui persentase praktikalitas perangkat pembelajaran matematika yaitu LAS dapat dilihat pada tabel 2 .

Tabel 2. Kriteria Praktikalitas

\begin{tabular}{|c|c|}
\hline Persentase & Kriteria \\
\hline $3,25 \leq x \leq 4,00$ & Sangat Praktis \\
\hline $2,50 \leq x \leq 3,25$ & Praktis \\
\hline $1,75 \leq x \leq 2,50$ & Cukup Praktis \\
\hline $1,00 \leq x \leq 1,75$ & Kurang Praktis \\
\hline
\end{tabular}

Suharsimi Arikunto, 2012

Perangkat pembelajaran yang dikembangkan peneliti dikatakan praktis apabila persentase praktikalitas yang diperoleh dari data angket respon peserta didik menunjukkan skor lebih dari 2,5. Artinya, perangkat pembelajaran LAS yang dikembangkan harus mencapai kategori minimal praktis.

\section{HASIL DAN DISKUSI}

Penelitian ini merupakan penelitian pengembangan perangkat pembelajaran materi Barisan dan Deret berbasis model Problem Based Learning untuk memfasilitasi kemampuan pemecahan masalah matematis kelas X SMK/MAK. Penelitian ini menggunakan desain ADDIE (Analysis, Design, Development, Implementation and Evaluate). Berikut ini akan dipaparkan kegiatan yang dilakukan setiap tahap:

\section{Tahap Analysis (Analisis)}

Cakupan aktivitas yang dilakukan oleh peneliti pada tahap analisis yaitu analisis kebutuhan, analisis kurikulum, dan analisis karakteristik peserta didik. Sebagai langkah awal dilakukan analisis kebutuhan, analisis ini bertujuan untuk mengetahui harapan-harapan guru dalam proses pembelajaran 
sehingga dapat menjadi pertimbangan dalam menghasilkan perangkat pembelajaran yang sesuai target dan tepat guna (Zubaidi, 2017). Pada tahap ini diperoleh informasi terkait perangkat pembelajaran (Silabus, RPP dan LAS) yang digunakan oleh guru.

Perangkat pembelajaran yang selama ini digunakan hanya mengikuti model Discovery Learning saja tanpa pengimplementasian model pembelajaran yang lain. RPP yang disusun oleh guru tidak memenuhi kriteria komponen kelengkapan RPP seperti tidak mencantumkan fakta dan prinsip dari materi yang diajarkan, materi pelajaran yang disajikan di RPP hanya berupa sub judul materi pokok, serta instrumen penilaian masih belum lengkap yakni tidak mencantumkan indikator soal.

Analisis kurikulum dilakukan untuk mengetahui kategori kurikulum yang digunakan agar dapat disesuaikan dengan subjek penelitian. Kurikulum yang digunakan disekolah khususnya SMKN 2 Pekanbaru adalah kurikulum 2013 namun proses pembelajaran serta perangkat pembelajaran yang disusun tidak mengikuti ketentuan pelaksanaan kurikulum. Proses pembelajaran masih bersifat Teacher Learning Center, guru menjelaskan materi di depan kelas dan di akhir penjelasan guru memberikan latihan dari buku penerbit. Hasil wawancara dari beberapa orang siswa menyatakan bahwa materi yang sulit dipahami adalah materi barisan dan deret. Siswa sulit membedakan bagaimana pola barisan dan deret serta penerapan rumus saat mengerjakan soal. Bertolak dari permasalahan ini peneliti menentukan perangkat pembelajaran yang perlu dikembangkan adalah pada materi Barisan dan Deret di SMK/MAK. Materi ini berada pada KD 3.5 menganalisis barisan dan deret aritmetika dan KD 4.5 menyelesaikan masalah kontekstual yang berkaitan dengan barisan dan deret aritmetika serta KD 3.6 menganalisis barisan dan deret geometri dan KD 4.6 menyelesaikan masalah kontekstual yang berkaitan dengan barisan dan deret geometri.

Analisis karakteristik siswa bertujuan untuk mengidentifikasi karakter siswa yang disesuaikan dalam penyusunan perangkat pembelajaran. Menurut Piaget, anak dengan rentang umur 12 tahun keatas sebagai remaja awal berada pada tahap operasional formal. Dari pola berpikir, remaja tidak lagi terbatas pada pengalaman konkret namun dapat diajak berpikir secara abstrak. Remaja masa awal mampu membayangkan situasi rekaan sebagai hipotesis dari suatu permasalahan (Ibda, 2015). Setelah dilakukan wawancara dan observasi terhadap karakteristik siswa, peneliti memperoleh kesimpulan bahwa siswa masih mengalami kesulitan ketika mengikuti pembelajaran. Hal ini terlihat ketika siswa diminta menyelesaikan soal-soal, siswa kesulitan namun sebenarnya siswa telah memiliki pengetahuan dasar. Permasalahan ini mendorong peneliti untuk menyajikan perangkat pembelajaran yang dapat memfasilitasi kemampuan pemecahan masalah siswa yaitu melalui model Problem Based Learning.

\section{Tahap Design (Perancangan)}

Pada tahap ini dilakukan pembuatan produk awal (prototype). Perancangan perangkat pembelajaran mengacu kepada Permendikbud. Perancangan silabus berpedoman pada Permendikbud No. 22 Tahun 2016, Permendikbud No. 103 Tahun 2014 sebagai acuan perancangan RPP dan perancangan LAS disesuaikan dengan sintaks model PBL dan indikator Kemampuan Pemecahan 
Pengembangan Perangkat Pembelajaran Matematika Berbasis Problem Based Learning untuk Memfasilitasi Kemampuan Pemecahan Masalah Matematis Siswa Pada Materi Barisan dan Deret Kelas X SMK/MAK, Yasvialan Arianta, Titi Solfitri, Syarifah Nur Siregar

Masalah Matematis Siswa. Penyusunan perangkat pembelajaran ini menggunakan basis PBL dengan menyajikan tahapan pembelajaran pada RPP dan LAS sesuai sintaks PBL. Kemudian untuk penilaian Kemampuan pemecahan masalah matematis siswa disajikan soal evaluasi baik di RPP maupun LAS yang sesuai dengan indikator KPMM. Berikut beberapa gambaran perangkat pembelajaran yang dihasilkan pada perancangan awal dan setelah dilakukan revisi, berikut beberapa gambaran produk yang dikembangkan:

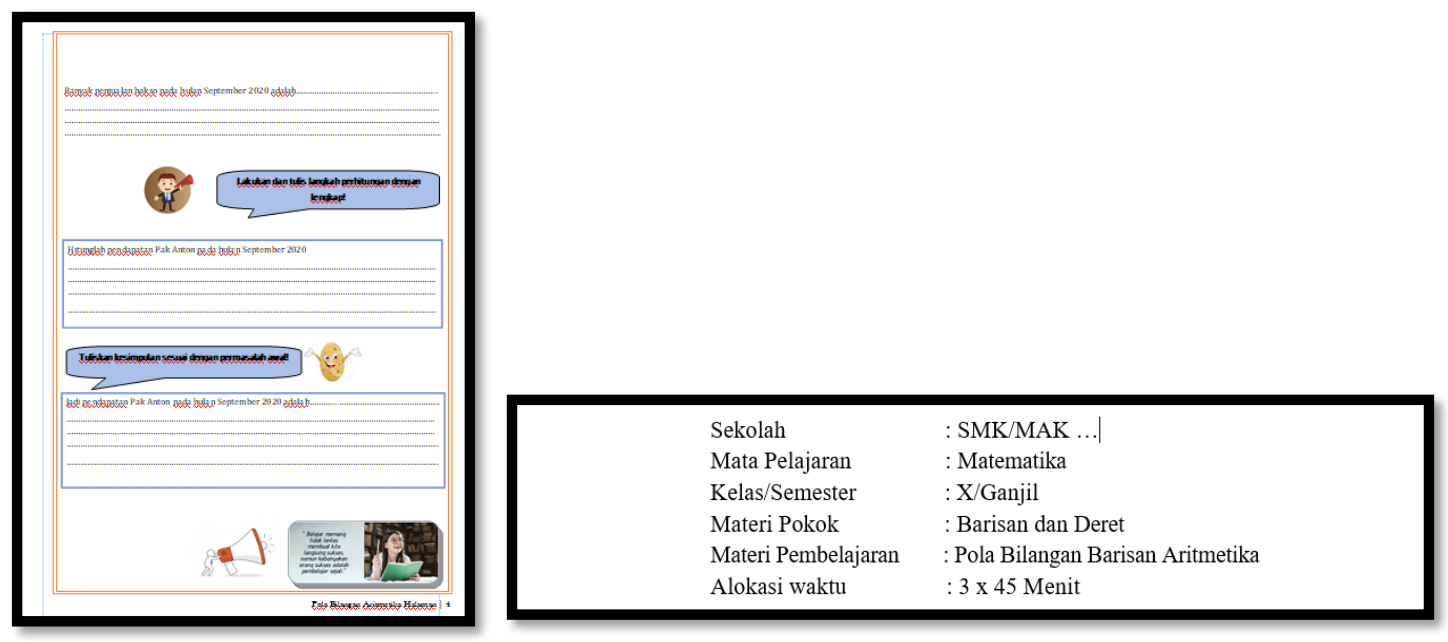

Gambar 3. Setelah direvisi

Rancangan LAS terbagi atas 4 judul materi antara lain pola bilangan barisan aritmetika, pola bilangan deret aritmetika, pola bilangan barisan geometri, dan pola bilangan deret geometri. Aktivitas peserta didik yang terdapat di dalam LAS yang disusun berdasarkan indikator Kemampuan Pemecahan Masalah Matematis (Hendriana dkk, 2017) dapat dijelaskan sebagai berikut:

1. Memahami masalah, pada fase ini disajikan masalah yang relevan dengan kehidupan sehari hari dan berkaitan dengan materi.

2. Merencanakan strategi pemecahan masalah, fase ini meminta siswa untuk menjawab dan menyelesaikan permasalahan yang telah disajikan di awal

3. Melaksanakan rencana pemecahan masalah, siswa melakukan pengolahan data dan Kembali melakukan perhitungan untuk mengecek benar atau salah dari jawaban yang ditulis

4. Menafsirkan hasil pemecahan masalah, siswa melakukan interpretasi dari hasil perhitungan sehingga diperoleh sebuah kesimpulan.

Pada tahap ini juga dihasilkan lembar validitas Silabus, RPP, dan LAS serta angket uji coba praktikalitas LAS.

\section{Tahap Development (Pengembangan)}

Produk awal yang telah dihasilkan pada tahap sebelumnya dilakukan validasi oleh 3 orang validator. Aspek penilaian dari validasi Silabus terdiri dari: 1) kelengkapan komponen Silabus, 2) kesesuaian KD dengan IPK dan materi pembelajaran, 3) kesesuaian langkah-langkah pembelajaran dengan model PBL dan pendekatan saintifik, 4) penilaian hasil belajar, 5) alokasi waktu, 6) sumber 
belajar, dan 7) bahasa. Hasil validasi Silabus yang telah peneliti analisis dapat dilihat pada Tabel 3 berikut.

Tabel 3. Hasil Validasi Silabus

\begin{tabular}{|c|c|c|c|c|c|}
\hline Aspek Materi & V1 & V2 & V3 & Rata-rata & Kategori Validasi \\
\hline 1 & 4,00 & 4,00 & 4,00 & 4,00 & Sangat Valid \\
\hline 2 & 3,00 & 4,00 & 3,66 & 3,55 & Sangat Valid \\
\hline 3 & 3,33 & 4,00 & 3,66 & 3,66 & Sangat Valid \\
\hline 4 & 3,25 & 3,50 & 3,50 & 3,42 & Sangat Valid \\
\hline 5 & 3,33 & 4,00 & 4,00 & 3,78 & Sangat Valid \\
\hline 6 & 3,33 & 4,00 & 3,66 & 3,66 & Sangat Valid \\
\hline 7 & 3,33 & 4,00 & 4,00 & 3,75 & Sangat Valid \\
\hline Rata-rata & $\mathbf{3 , 3 5}$ & $\mathbf{3 , 9 3}$ & $\mathbf{3 , 7 8}$ & $\mathbf{3 , 6 9}$ & Sangat Valid \\
\hline
\end{tabular}

Berdasarkan Tabel 3, skor rata-rata hasil validasi Silabus adalah 3,69 dengan kategori sangat valid. Perbaikan validator terhadap silabus meliputi perbaikan pada bagian kelengkapan silabus, validator menyarankan agar memperbaiki kolom kegiatan pembelajaran agar satu materi yang disajikan dimuat dalam satu lembar.

Aspek materi dari validasi RPP terdiri dari: 1) kelengkapan komponen RPP, 2) kejelasan Indikator Pencapaian Kompetensi, 3) kejelasan rumusan tujuan pembelajaran, 4) materi pembelajaran, 5) alat, media, dan sumber belajar, 6) komponen pembelajaran berbasis model PBL, dan 7) penilaian hasil belajar, dan 8) bahasa. Hasil validasi RPP yang telah peneliti analisis dapat dilihat pada Tabel 4 berikut.

Tabel 4. Hasil Validasi RPP

\begin{tabular}{|c|c|c|c|c|c|}
\hline Aspek Materi & V1 & V2 & V3 & Rata-rata & Kategori Validasi \\
\hline 1 & 4,00 & 4,00 & 4,00 & 4,00 & Sangat Valid \\
\hline 2 & 3,00 & 4,00 & 3,66 & 3,55 & Sangat Valid \\
\hline 3 & 3,33 & 4,00 & 3,66 & 3,66 & Sangat Valid \\
\hline 4 & 3,25 & 3,50 & 3,50 & 3,42 & Sangat Valid \\
\hline 5 & 3,33 & 4,00 & 4,00 & 3,78 & Sangat Valid \\
\hline 6 & 3,33 & 4,00 & 3,66 & 3,66 & Sangat Valid \\
\hline 7 & 3,33 & 4,00 & 4,00 & 3,75 & Sangat Valid \\
\hline Rata-rata & $\mathbf{3 , 3 5}$ & $\mathbf{3 , 9 3}$ & $\mathbf{3 , 7 8}$ & $\mathbf{3 , 6 9}$ & Sangat Valid \\
\hline
\end{tabular}

Berdasarkan Tabel 4, skor rata-rata hasil validasi RPP adalah 3,67 dengan kategori sangat valid. Perbaikan validator terhadap RPP meliputi komponen dan isi RPP. Pada bagian komponen, validator menyarankan untuk menulis nama sekolah secara umum agar dapat digunakan secara universal. Pada bagian isi validator menyarankan untuk mencantumkan wacana permasalahan dalam sintaks RPP secara keseluruhan kemudian perbaikan konsep dan fakta yang disajikan pada materi pembelajaran.

Aspek penilaian dari validasi LAS adalah: 1) komponen LAS, 2) kesesuaian materi pembelajaran, 3) kualitas kegiatan pembelajaran, 4) kesesuaian proses KPMM dengan model PBL, 5) kesesuaian dengan syarat didaktis, 6) kesesuaian dengan syarat konstruksi, 7) kesesuaian dengan syarat teknis. Hasil validasi LAS yang telah penulis analisis dapat dilihat pada tabel 5 berikut: 
Pengembangan Perangkat Pembelajaran Matematika Berbasis Problem Based Learning untuk Memfasilitasi Kemampuan Pemecahan Masalah Matematis Siswa Pada Materi Barisan dan Deret Kelas X SMK/MAK, Yasvialan Arianta, Titi Solfitri, Syarifah Nur Siregar

Tabel 5. Hasil Validasi LAS

\begin{tabular}{|c|c|c|c|c|c|}
\hline Aspek Materi & V1 & V2 & V3 & Rata-rata & Kategori Validasi \\
\hline 1 & 4,00 & 4,00 & 4,00 & 4,00 & Sangat Valid \\
\hline 2 & 3,00 & 4,00 & 3,66 & 3,55 & Sangat Valid \\
\hline 3 & 3,33 & 4,00 & 3,66 & 3,66 & Sangat Valid \\
\hline 4 & 3,25 & 3,50 & 3,50 & 3,42 & Sangat Valid \\
\hline 5 & 3,33 & 4,00 & 4,00 & 3,78 & Sangat Valid \\
\hline 6 & 3,33 & 4,00 & 3,66 & 3,66 & Sangat Valid \\
\hline 7 & 3,33 & 4,00 & 4,00 & 3,75 & Sangat Valid \\
\hline Rata-rata & $\mathbf{3 , 3 5}$ & $\mathbf{3 , 9 3}$ & $\mathbf{3 , 7 8}$ & $\mathbf{3 , 6 9}$ & Sangat Valid \\
\hline
\end{tabular}

Berdasarkan Tabel 5, skor rata-rata hasil validasi sebesar 3,68 dengan kategori sangat valid. Perbaikan validator terhadap LAS yakni penambahan kalimat motivasi di beberapa bagian dalam LAS. Hal ini bertujuan untuk menambah ketertarikan siswa terhadap LAS yang disajikan.

\section{Tahap Implementation (Implementasi)}

Pada tahap ini peneliti melakukan uji coba praktikalitas terhadap produk yang sudah dikembangkan untuk mengetahui kepraktisan LAS dengan model PBL. LAS yang dinyatakan valid diujicobakan dalam uji coba kelompok kecil. Uji coba dilakukan pada 9 orang siswa kelas X SMKN 2 Pekanbaru. Uji coba dilakukan secara online melalui platform Zoom Meeting dan WhatsApp Group. Pelaksanaan uji coba berlangsung selama 4 hari. Peneliti memberikan uji coba LAS 1 pada hari pertama, LAS 2 pada hari kedua, LAS 3 pada hari ketiga dan LAS 4 di hari keempat.

Peneliti membagikan LAS dalam format pdf dan link meeting yang digunakan melalui WhatsApp Group. Sebelum melakukan dan menyelesaikan kegiatan-kegiatan yang ada pada LAS, peneliti menjelaskan secara singkat mengenai petunjuk pengerjaan. Pada saat pengerjaan LAS, peneliti bertindak sebagai pendamping dan pembimbing yang memberikan arahan jika siswa mengalami kesulitan selama pengerjaan. Proses pengerjaan LAS oleh siswa berlangsung selama 45 menit. Siswa menuliskan jawaban LAS pada kertas kemudian setelah waktu pengerjaan berakhir siswa diminta mengirimkan jawaban secara pribadi ke WhatsApp peneliti. Berdasarkan pengamatan peneliti, siswa terlihat antusias dalam melakukan kegiatan yang terdapat pada LAS dan bertanya kepada peneliti jika mengalami kebingungan.

\section{Tahap Evaluation (Evaluasi)}

Pada tahap ini, peneliti menganalisis data angket respon siswa untuk melihat kepraktisan LAS yang peneliti kembangkan. Setelah pengerjaan LAS selesai, peneliti meminta respon peserta didik dengan membagikan angket praktikalitas. Hasil analisis data praktikalitas dapat dilihat pada tabel 6 .

Tabel 6. Hasil Praktikalitas LAS

\begin{tabular}{|c|c|c|c|c|c|c|}
\hline \multirow{2}{*}{$\begin{array}{l}\text { Perangkat } \\
\text { pembelajaran }\end{array}$} & \multicolumn{4}{|c|}{ Persentase angket respon (\%) LAS- } & \multirow[t]{2}{*}{ Rata-rata } & \multirow[t]{2}{*}{ Kategor } \\
\hline & 1 & 2 & 3 & 4 & & \\
\hline LAS & 3,16 & 3,28 & 3,17 & 3,26 & 3,22 & Praktis \\
\hline
\end{tabular}


Berdasarkan hasil analisis terhadap angket respon siswa pada uji coba kelompok kecil diperoleh skor rata-rata praktikalitas sebesar 3,22 dengan kategori praktis. Hal ini menyatakan bahwa LAS dengan model PBL yang dikembangkan dinilai telah baik untuk digunakan sebagai alternatif perangkat pembelajaran dengan model PBL pada materi Barisan dan Deret.

\section{Diskusi}

Berdasarkan analisis hasil validasi silabus oleh validator, rata-rata hasil validasi silabus adalah 3,69 dikategorikan sangat valid. Berdasarkan analisis hasil validasi RPP oleh validator, rata-rata hasil validasi RPP adalah 3,67 dikategorikan sangat valid. Berdasarkan analisis hasil validasi LAS oleh validator, rata-rata hasil validasi LAS adalah 3,68 dikategorikan sangat valid.

Kemudian untuk uji praktikalitas telah dilakukan uji coba satu satu terhadap 9 orang siswa SMKN 2 pekanbaru dengan hasil skor angket sebesar $80,49 \%$ dengan kategori sangat praktis. Namun pada penelitian ini belum dilakukan uji keefektifan produk.

\section{KESIMPULAN}

Perangkat pembelajaran berbasis Problem Based Learning (PBL) pada materi Barisan dan Deret yang terdiri dari Silabus, RPP, dan LAS sudah dikategorikan sangat valid dengan persentase rata-rata dari seluruh kelayakan sebesar 3,68. Hasil praktikalitas LAS sebesar 3,22 dengan kategori praktis. LAS yang dikembangkan telah layak digunakan sebagai sumber belajar bagi siswa, karena dapat menuntun siswa dengan tahapan pembelajaran PBL dalam memahami konsep Barisan dan Deret. Silabus dan RPP dapat telah layak dijadikan alternatif perangkat pembelajaran yang digunakan oleh guru.

\section{REFERENSI}

Amalya, L. (2019). Pengembangan Perangkat Pembelajaran Matematika Problem Based Learning Berbasis Teknologi Informatika pada siswa SMK Tritech Informatika Medan TP. 2018/2019. In Resipotory UIN Sumatera Utara (Vol. 8, Issue 5). UIN Sumatera Utara.

Erna, A., Zulkarnain, Rezi, I. (2019). Pengembangan Perangkat Pembelajaran Matematika dengan PBL pada Materi Sistem Persamaan Linear Tiga Variabel di Kelas X SMK Yabri Terpadu Pekanbaru. Aksiomatik. 7(1)

Goenawan R. \& Sri H. (2017). Pemecahan Masalah Matematika untuk PGSD. PT Remaja Rosdakarya. Bandung

Hendriana, dkk. (2017). Hard Skills dan Soft Skills Matematika Siswa. Refika Aditama. Bandung Ibda, F. (2015). Perkembangan Kognitif: Teori Jean Piaget. Intelektualita, 3(1), 23-28.

Kementerian Pendidikan dan Kebudayaan. 2016. Permendikbud No.22 tahun 2016. Standar Proses Pendidikan Dasar dan Menengah. Menteri Pendidikan dan Kebudayaan Republik Indonesia. Jakarta 
Pengembangan Perangkat Pembelajaran Matematika Berbasis Problem Based Learning untuk Memfasilitasi Kemampuan Pemecahan Masalah Matematis Siswa Pada Materi Barisan dan Deret Kelas X SMK/MAK, Yasvialan Arianta, Titi Solfitri, Syarifah Nur Siregar

Kementerian Pendidikan dan Kebudayaan. 2018. Permendikbud No. 34 tahun 2018. Standar Nasional

Pendidikan Sekolah Menengah Kejuruan (SMK) / Madrasah Aliyah Kejuruan (MAK).

Menteri Pendidikan dan Kebudayaan Republik Indonesia. Jakarta

Khomsiatun, S., \& Retnawati, H. (2015). Pengembangan Perangkat Pembelajaran Dengan Penemuan

Terbimbing Untuk Meningkatkan Kemampuan Pemecahan Masalah. Jurnal Riset Pendidikan Matematika, 2(1), 92-106.

Masjudin. 2016. Pembelajaran Kooperatif Investigatif Untuk Meningkatkan Pemahaman Siswa Materi Barisan dan Deret. JEMS. 4(2). 76-84.

Murtikusuma, R. P. 2015. Pengembangan Perangkat Pembelajaran Matematika Model Problem Based Learning Berbantuan Media PowerPoint Untuk Siswa Kelas X SMK Materi Barisan dan Deret. Jurnal Saintifika. 17(2). 20-32.

Purnomo, D. (2011). Pengembangan Bahan Ajar Matematika Sebagai Sarana Pengembangan Kreativitas Berpikir. Aksioma: Jurnal Matematika Dan Pendidikan Matematika UPGRIS Semarang, 2(1), 1-8.

Suharsimi Arikunto. 2012. Dasar-Dasar Evaluasi Pendidikan. Jakarta. Bumi Aksara

Sulastri, R. 2017. Identifikasi Kendala dan Masalah dalam Proses Pembelajaran Matematika. Prosiding Seminar Nasional Kemaritiman Aceh, 1. Universitas Serambi Mekkah. Banda Aceh.

Suprihatiningrum, J. (2013). Strategi Pembelajaran Teori dan Aplikasi. Ar-ruzz Media. Yogyakarta

Wulandari, B., \& Surjono, H. D. (2013). Pengaruh problem-based learning terhadap hasil belajar ditinjau dari motivasi belajar PLC di SMK. Jurnal Pendidikan Vokasi, 3(2), 178-191. https://doi.org/10.21831/jpv.v3i2.1600

Zubaidi, A. (2017). Model-Model Pengembangan Kurikulum dan Silabus Pembelajaran Bahasa Arab. Cendekia, 13(1), 100. 